\title{
A new dawn for buried garbage?: An investigation of the marketability of previously disposed shredder waste
}

\author{
Nils Johansson, Joakim Krook and Per Frändegård
}

\section{Linköping University Post Print}

\section{Tweet}

N.B.: When citing this work, cite the original article.

Original Publication:

Nils Johansson, Joakim Krook and Per Frändegård, A new dawn for buried garbage?: An investigation of the marketability of previously disposed shredder waste, 2016, Waste Management.

http://dx.doi.org/10.1016/j.wasman.2016.05.015

Copyright: Elsevier

http://www.elsevier.com/

Postprint available at: Linköping University Electronic Press

http://urn.kb.se/resolve?urn=urn:nbn:se:liu:diva-129541

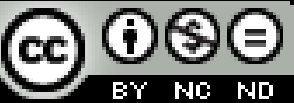




\title{
A NEW DAWN FOR BURIED GARBAGE? AN INVESTIGATION OF THE MARKETABILITY OF PREVIOUSLY DISPOSED SHREDDER WASTE
}

\author{
N. JOHANSSON ${ }^{a^{*}}$, J. KROOK ${ }^{a}$, P. FRÄNDEGÅRD ${ }^{a}$. \\ a Department of Management and Engineering, Environmental Technology and Management Linköping \\ University, SE-581 83 Linköping, Sweden. Nils.johansson@liu.se \\ * Corresponding author at: Department of Management and Engineering, Environmental Technology and \\ Management Linköping University, SE-581 83 Linköping, Sweden. Tel.: +46 132856 29. Email: \\ Nils.johansson@liu.se
}

\begin{abstract}
This paper examines the market potential of disposed shredder waste, a resource that is increasingly emphasized as a future mine. A framework with gate requirements of various outlets was developed and contrasted with a pilot project focusing on excavated waste from a shredder landfill, sorted in an advanced recycling facility. Only the smallest fraction by percentage had an outlet, the metals (8\%), which were sold according to a lower quality class. The other fractions (92\%) were not accepted for incineration, as construction materials or even for re-deposition. Previous studies have shown similar lack of marketability. This means that even if one fraction can be recovered, the outlet of the other material is often unpredictable, resulting in a waste disposal problem, which easily prevents a landfill mining project altogether. This calls for marketability and usability of deposited waste to become a central issue for landfill mining research. The paper concludes by discussing how concerned actors can enhance the marketability, for example by pre-treating the disposed waste to acclimatize it to existing sorting methods. However, for concerned actors to become interested in approaching unconventional resources such as deposited waste, greater regulatory flexibility is needed in which, for example, re-deposition could be allowed as long as the environmental benefits of the projects outweigh the disadvantages.
\end{abstract}

KEYWORDS: Landfill mining, disposed waste, marketability, policy, technology.

\section{INTRODUCTION}

Today, the increasing demand for resources is mainly met by traditional extractive industries searching for previously inaccessible reserves, accompanied by severe social and ecological consequences. Recycling can partly substitute for primary production, but the waste streams are too small to cover a significant share of the increasing demand for resources, especially for critical metals, such as rare earth elements. However, due to our inherent wastefulness, huge amounts of material and energy resources have accumulated in different waste deposits. Some researchers claim that such deposits are bursting with resources, e.g., globally the deposited amount of copper is comparable to the current in-use stock (Kapur, 
2006), and in some regions, the amount of landfilled combustibles could potentially cover the demand for district heating for decades (Frändegård et al., 2013). Given this potential, the extraction of inactive resources has been proposed as an alternative strategy to quantitatively increase recycling and thereby replace a more significant share of primary production (Ayres, 1999; Johansson et al., 2013). Such a resource strategy could lead to avoided climate emissions from primary production (Frändegård et al., 2013), an opportunity to treat hazardous substances in the landfill and thus a better local environment (Johansson et al., 2012), and strengthened local economies by job creation (Jones et al., 2013). Extracting landfills, i.e., landfill mining could also have geopolitical advantages if it leads to a reduction in imports of metals and minerals. Such innovative resource extraction operations are thus closely related to several national (Swedish EPA, 2012; Swedish Government, 2013) and international (European Commission, 2008) policy objectives such as increased recycling, resource conservation, reduced climate impact and remediation of contaminated land.

Landfill mining is an emerging research field, which is limited to the mapping of small-scale pilot studies (Krook et al., 2012) when it comes to landfill material composition (e.g., Hull et al., 2005; Cossu et al., 1996; Hogland et al., 2004; Quaghebeur et al., 2013), applicability of different technologies (e.g. Dickinson, 1995; Reeves and Murray, 1997; Zhao et al., 2007; Bosmans et al., 2013), environmental and health risks (Cossu et al., 1995; EPA, 1997), and economic feasibility (e.g. Fisher and Findlay, 1995; Dickinson, 1995; Hull et al., 2005). Given this lack of real-life projects, conducted assessments about the resource potential of landfills (Hogland et al., 2004; Tahna and Zarate, 2012) and related economic and environmental impacts of realizing such full-scale mining operations rely on hypothetical conditions and cases (Frändegård et al., 2013; van Passel et al., 2013; Winterstetter et al., 2015). Although useful for pinpointing the potential, such an approach is insufficient because it builds upon assumptions about landfill mining fundamentals in terms of technical feasibility and market acceptance of the extracted resources.

Indeed, some reports state that deposited waste has been recovered in previous landfill mining operations. For example, extracted soil-type material has been used as fertilizer (e.g. Savage et al., 1993), separated combustibles as fuel in waste incinerators (e.g. Johansson et al., 2012), and different types of metals have been material recycled (e.g. Hino et al., 1998; Zanetti and Godio, 2006). However, several of these cases were performed during a time when environmental standards were lacking or at least significantly lower than what is normally the case today. Others involved pilot studies, in which only small quantities of waste were sent to material and energy companies on a trial basis without any need for material characterization or fulfilment of current market and regulatory demands.

Generally, the marketability of materials and energy resources from landfills has received limited attention, often only examined in passing in some studies. Therefore, the conclusions about market acceptance have often been incomplete or even inadequate. For instance, several previous studies provide a limited picture of the outlets since they only address the marketability of a few selected materials (e.g. Kaartinen et al., 2013; Prechthai et al., 2008; Hogland et al., 1995; Kornberg et al., 1993). This is problematic given that both the economic and environmental motives of any landfill mining initiative assume that most of the extracted materials can be recovered (e.g. Frändegård et al., 2013; Frändegård et al., 2015; van Passel et al., 2013; Winterstetter et al., 2015; Jain et al., 2015). In other cases, the waste was manually sorted prior to analysis - something which hardly reflects the characteristics of the material 
fractions that would be obtained in a full-scale mechanical operation (cf. Quaghebeur et al., 2013; Zhou et al., 2014). In principle, these incoherencies do not provide a sufficient basis for understanding if it is possible to find use for all of the exhumed material and thus obtain salable recyclables from waste deposits - essential knowledge for justifying any landfill mining operation as well as for evaluating the resource potential of such deposits in a circular economy.

The purpose of this study is to systematically examine the marketability of all material fractions generated from a landfill mining pilot project in Sweden. In doing so, a comprehensive framework for assessing possible outlets and related market and regulatory criteria is developed and contrasted to the physical and chemical properties of the separated materials. Apart from assessing if the market is ready to take back the material it once abandoned, such an analytical approach makes it possible to specify which critical criteria determine the usability of the different materials. Based on these fine-grained results, technical and regulatory measures for further improving the marketability of landfill mining materials are discussed. The market acceptance is limited in this study to gate requirements of downstream material and energy companies and accompanying regulations and laws.

\section{METHOD}

The method applied to investigate the marketability of previously deposited waste can be structured into six main sections, as seen in Figure 1. First, (1) a landfill intended to be extracted was identified, which could serve as a starting point and frame the analytical approach. Then a framework for waste outlets was constructed by (2) identifying potential outlets and (3) mapping associated input requirements and regulatory demands for accepting the waste. The extracted material was (4) analyzed and (5) contrasted to the framework in order to explore the marketability, and finally (6) opportunities for further refining were investigated. 


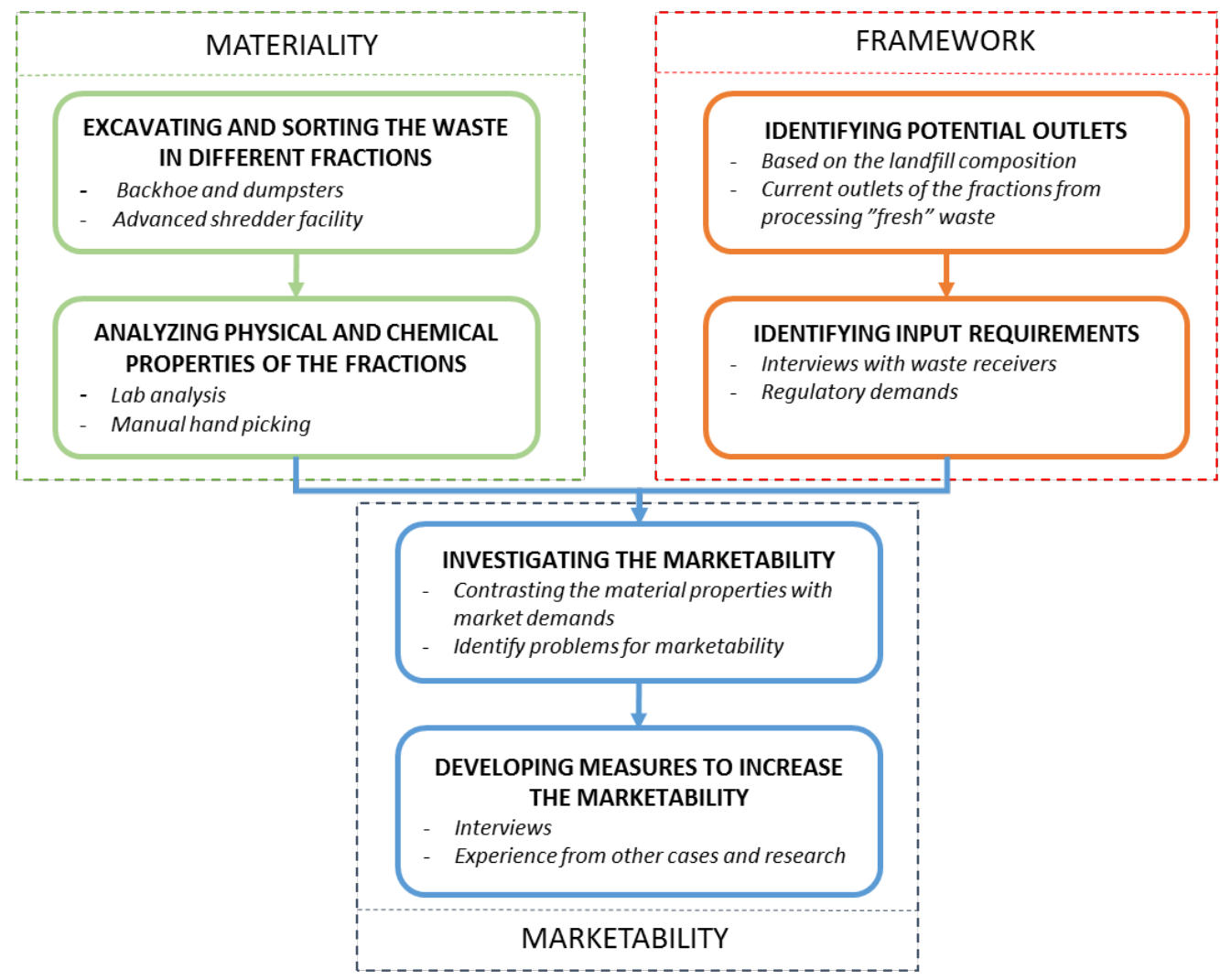

Figure 1. A schematic overview of the methodological approach of this study. The points listed in each box indicates the procedures to collect information for the specified methodological step. However, the figure is a simplification. For example, the identification of potential outlets in the red box directly influenced the choice of analytical methods for the sorted fractions in the green box.

\subsection{Methodological background: A landfill mine}

The landfill in focus in this study is an industrial shredder landfill in Sweden. This landfill contains about 650,000 tonnes of waste, mainly from the processing of scrap cars and metal scrap collected at recycling centers. The landfill opened in 1975 and is about 10 meters high, at its highest point. During 2013-2014, the owner of the landfill extracted 600 tonnes of disposed material from a specific part of the landfill. This section was chosen since it was easily accessible for the involved machines, a backhoe and dumpster, and assumed to hold a particularly high content of non-ferrous metals. Previous internal evaluations had indicated that at this particular location, shredder waste had been deposited before 1985 when only iron was sorted from the incoming scrap, consequently with remaining high levels of non-ferrous metals. The pilot excavation was thus mainly resource-driven to investigate the potential in recycling metals. Besides exploring the opportunities for a new supply to the core business of metal recycling, the company was also interested in investigating the possibility of regaining landfill space as the current landfill is estimated to run out of space in approximately 15 years. Thus, in order to create as much space as possible, the company was interested in the possibilities of recovering all types of material, not only metals. 
After the excavation, the previously disposed waste was stored for three months under tarpaulins to dry. The stored waste was then processed in a similar separation facility as the flow of everyday incoming "fresh" waste to the company, which is an advanced fragmentation plant, optimized for metal recycling, located within a kilometer of the landfill. Thus, the waste was sorted through magnets, eddy current, air knife, screening, washing and flotation, into several different waste fractions which could essentially be categorized as fines, shredder light fraction (SLF), metals, heavy waste and light waste, as seen in Table 1. Since many of the sorting steps, in particular screeners and magnets, are repetitive in the process flow, fines and metals were churned out at several different places in the recycling process.

Table 1. This table shows the fractions sorted from the advanced shredder facility, the originated sorting method, the material balance from the pilot excavation, their main characteristics, and traditional disposal option when "fresh" waste is processed.

\begin{tabular}{ccccc}
\hline Fraction & Sorting method & Material balance & Main characteristics & Traditional Outlets \\
\hline Fines & Screen & $55 \%$ & material dimension less than $2 \mathrm{~cm}$ & landfilled \\
SLF & Air Knife & $11 \%$ & lightweight materials such as foam & incinerated \\
Light waste & Flotation & $6 \%$ & lighter material such as textiles & incinerated \\
Heavy waste & Flotation & $20 \%$ & heavy materials such as rubber & landfilled \\
Metals & Magnets & $8 \%$ & ferrous and non- ferrous metals & recycled
\end{tabular}

\subsection{Constructing the framework}

To investigate the marketability of the excavated waste, a framework was constructed. To specify and limit the number of potential outlets, interviews with three experts at the executive recycling company were conducted: the landfill manager, process manager and sales manager. Questions were formulated around the main issue: "What potential outlets for the previously disposed waste can you identify?" Examples of sub-questions were "What is the current outlets for fractions from sorted "fresh" waste?"; "What potential outlets can you identify for the fractions fines/SLF/metals/heavy waste/light waste and metal/rubber/plastic/inert material?"; and "What are the pros and cons of your suggested outlets?" All outlets have been proposed by the respondents based on the preconditions of the material inside the landfill (for the material composition, see Alm et al., 2006) or are current outlets for separated, fresh waste from the fragmentation plant.

The first step in constructing the framework was to identify possible outlets for the disposed waste emanating from the waste hierarchy: disposal, construction material ${ }^{1}$, energy recovery and material recycling. Other parts from the waste hierarchy such as re-use and biological treatment were excluded from the framework due to the nature of the disposed waste. Re-use is not applicable since most of the material has been shredded in the fragmentation facility. Biological treatment such as biogas production is not applicable since easily biodegradable material is most likely already transformed in the landfill.

\footnotetext{
${ }^{1}$ Formally, the waste hierarchy includes the following steps: prevention, re-use, material recycling, energy recovery and disposal (European Commission, 2008). Construction material is not included as a category in the waste hierarchy. However, it is difficult to categorize construction material according the formal steps, since it means that waste material is used as a resource (in construction) but commonly not according to its original purpose
} 
Swedish biogas producers are also assigned to a standard (SPCR 120) which only accepts waste from the food and agriculture sector.

Each step of the waste hierarchy (disposal, construction materials, energy recovery and material recycling) can, however, imply big variations. For example, energy recovery could include conventional methods such as waste incineration as well as methods on the research level such as gas-plasma. In this study, we have chosen to include only conventional methods that are commercially established in the proximity of Sweden, as our focus is what currently can be done with the waste at the same time as conventional methods are more likely to have established gate requirements. However, there is also a wide variation of commercially operating waste management practices. For example, waste could be deposited in a variety of contexts, from an inert landfill to an old mine in Norway, Langøya. However, some conventional waste management practices were identified as irrelevant by the respondents. For example, landfilling in Langøya was considered unrealistic because of the costs. Furthermore, paper and glass recycling were excluded as the landfill in question contains small amount of paper and glass according to Alm et al. (2006). But as the landfill contains large amount of rubber, pyrolysis was identified as a potential outlet, given that this is a commercially established method in Sweden to recycle rubber. Overall, through the interviews, the following potential outlets for the disposed waste could be specified:

- Deposition of waste in either a hazardous landfill or a non-hazardous landfill with lower requirements.

- Construction material is waste that can be used freely in various construction works ${ }^{2}$ such as roads, residential sites or as covering of landfills with lower requirements.

- Energy recovery of waste, a fuel either in a traditional grate boiler, circulating fluidized bed (CFB) or in cement production.

- Recycling of metals, plastics and rubber (pyrolysis).

When the potential outlets were identified, the gate requirements in Sweden for accepting waste were mapped for each included waste management practice, i.e., the minimum quality of waste to be, for example, landfilled or recycled. The possibilities for finding an outlet are, however, as demonstrated in research assessing outlets for traditional, "fresh" waste (e.g. Van Gerven, 2005; Alburquerque et al., 2012), not only determined by the waste recipients but also, although often integrated into the gate requirements, by legal limits and requirements on waste. The requirements for receiving waste also have different character depending on the waste management practice. For some waste management practices general requirements are specified in the legislation, but in other cases it is primarily up to the individual actor to decide the required quality. Thus, information was not only collected from direct interviews with waste recipients, but also from Swedish (e.g. Swedish EPA, 2004:10; 2010) and European legislative texts (European Parliament, 2009). Hence, legal requirements and the input criteria of the included waste management practices formed a market framework for secondary resources.

\footnotetext{
${ }^{2}$ In Sweden, there are only guidelines for using waste in various construction works as well as covering landfills. There is no specified requirement for using waste for differentiated purposes such as establishing industrial or residential sites. The licensing authority may, however, if registration is provided and based on the specific conditions, use state (less strict) site-specific limits for the use of waste as construction material.
} 
For deposition (Swedish EPA, 2004:10) and construction material (Swedish EPA, 2010) there are limits for leaching concentrations and total concentrations, working as guiding requirements in the framework, as seen in Figure 2. Waste incineration is also a relatively regulated market but the input requirements, i.e., ash, moisture, chlorine, heavy metals and calorific concentrations are determined by each actor based, for example, on the type of boiler (grate or CFB) and the purpose: waste incineration (grate and CFB) or cement production. To determine the input criteria for waste incineration, the guidelines of the industry association were used in the framework. The recycling market, on the other hand, is not as legally controlled, since it is primarily up to the individual recycler to determine how to make a good deal. A general requirement of recyclers is that the incoming material shall not be heterogenic, i.e., a high concentration of plastic or metals is required. The REACH agreement (European Parliament, 2009), however, indirectly regulates receivable levels of heavy metals and other substances for the recycling sector. Input criteria for material recycling was obtained by interviewing significant recyclers in Sweden. For this reason, the requirements for landfilling, construction material and energy recovery are presented quantitatively in a comparative table in the appendix, while the requirements of recycling are reported qualitatively in the same appendix.

\begin{tabular}{|c|l|}
\hline & TYPE OF INPUT CRITERIA \\
\hline \multicolumn{1}{|c|}{ RECYCLE } & INCINERATION \\
\hline $\begin{array}{l}\text { CONSTRUCTION } \\
\text { MATERIAL }\end{array}$ & \\
\hline LANDFILL & 0 \\
\hline
\end{tabular}

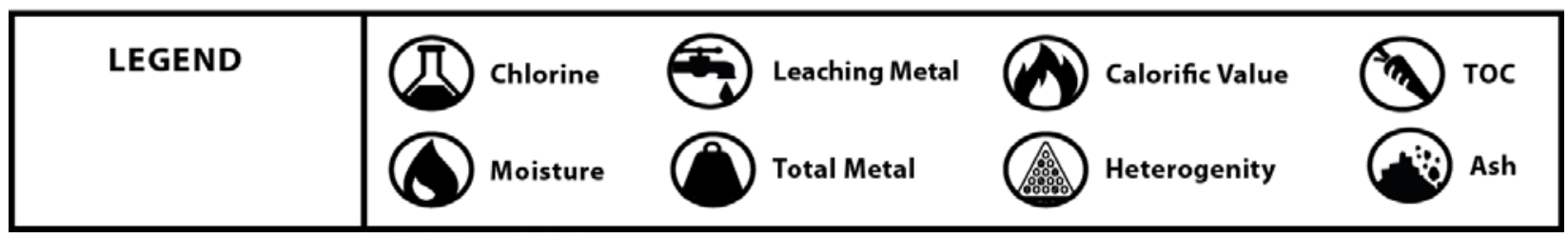

Figure 2. Overview of the market and regulatory criteria for the identified waste outlets in the constructed framework.

\subsection{Analyzing the buried waste}

The next step was to return to the sorted excavated waste (fines, SLF, metals, heavy waste and light waste) to explore the marketability according to the different criteria identified above. Each output was lab analyzed for moisture, ash, carbon, hydrogen, nitrogen, oxygen, sulfur, chlorine, fluorine, bromine, main elements, trace elements and calorific value to determine leaching concentrations, total concentrations and heating value, according to Figure 2 . The rest was screened and material above $4 \mathrm{~mm}$ was manually 
sorted in nine different material fractions ${ }^{3}$ with the help of magnets, knives, hands, and visual inspection. Material with a dimension below $4 \mathrm{~mm}$ was too small to be manually sorted, and therefore presented as undetectable in Table 2. This means that the estimated share of each material type is conservative, especially in the fractions with a high share of fine material. The manual hand sorting was done to take a closer look at the material and, for example, determine heterogeneity and potential for refining. The results from the lab analysis and material characterization of each fraction, i.e., the leaching and total concentration, heating value and heterogeneity, were then compared with market requirements in our framework to explore the marketability of the separated waste, i.e., could the sorted fractions from the landfill be re-disposed, used as construction material, energy recovered or material recycled?

However, as several fractions demonstrated almost identical properties in terms of e.g. material composition and heavy metal concentrations, some fractions have been jointly presented in the framework, see chapter 3. Thus, all the various fractions of fines and metals were merged into one fine fraction and one metal fraction, respectively. Additionally, heavy waste, light waste and SLF proved to have similar properties and were therefore presented under the same heading. When there were differences between the fractions in the same group, dissimilarities were presented as seen in chapter 3.

\subsection{Upgrading the marketability}

When the marketability was investigated for the sorted waste, the reasons for why the material could not be utilized for landfilling, construction material, incineration or recycling were simultaneously identified. For example, in a specific fraction the level of heavy metals was identified above the limits for construction material. This analysis demonstrates both the marketability of construction material for this fraction, and simultaneously the problem that must be solved for the specific fraction to be used as construction material. The identified problems, in chapter 3 , were thus used as a basis for discussing ways of increasing the marketability, as presented in chapter 4.

Since technical and legal measures influence the market acceptance of waste, both aspects were also considered when discussing how to enhance the marketability of the previously deposited waste. Again, only conventional strategies commercially available in Sweden were included. For example, the solution for the problem identified above of high levels of heavy metals, could be technical methods to reduce the heavy metal content and/or legal approaches, which brings focus to the legal requirements on the material. The discussion on how to upgrade the marketability of the waste was based on interviews with experts at the executive recycling company through asking questions such as "What technical/legal approach, considering the problems identified, could enhance the marketability of the fractions?" To anchor the suggestions from the interviews in practicality, the suggestions were related to research on waste management methods, landfill mining and experience in regulating waste markets in other European countries.

\footnotetext{
${ }^{3}$ Rubber, hard plastics, foam, soft plastic, textiles, wood, ferrous, nonferrous and inert.
} 


\section{EXPLORING THE MARKET POTENTIAL}

\subsection{Fines}

The largest fraction that came out from the stationary separation facility was fines. This fraction represented over $50 \%$ of the excavated material, as seen in Table 1, and contained mostly rubber, hard plastics, textiles and some metals, as seen in Table 2.

Table 2. The material composition of the separated fractions.

\begin{tabular}{ccccc}
\hline Fraction & Sorting method & Material balance & Main characteristics & Traditional Outlets \\
\hline Fines & Screen & $55 \%$ & material dimension less than $2 \mathrm{~cm}$ & landfilled \\
SLF & Air Knife & $11 \%$ & lightweight materials such as foam & incinerated \\
Light waste & Flotation & $6 \%$ & lighter material such as textiles & incinerated \\
Heavy waste & Flotation & $20 \%$ & heavy materials such as rubber & landfilled \\
Metals & Magnets & $8 \%$ & ferrous and non- ferrous metals & recycled
\end{tabular}

It is difficult to find any potential outlet for fines. Considering the large portion of fine material in fines ${ }^{4}$ (59\%) and especially the heterogeneity, it would probably be difficult to recycle the materials contained in fines. Although fines contain around $10 \%$ plastic, it is still far from the required $90 \%$ for recycling (see appendix for detailed input criteria). Also, the total lead content in fines (>3000 mg/kg), as seen in Table 3 , is far higher than the limits of REACH $(100 \mathrm{mg} / \mathrm{kg})$, which must be followed by recyclers. The high chlorine content, around $2 \%$, as seen in Table 4, indicates the presence of PVC, which is not accepted by plastic recyclers. However, it could be interesting to re-process the fine fraction in the separation facility due to a content of around 3\% metals, as metal recyclers are commonly less sensitive to heterogeneity and the presence of heavy metals.

Table 3. Total concentrations of heavy metals $(\mathrm{mg} / \mathrm{kg})$ in the separated fractions and according to the limits for construction material, landfill cover and waste incineration.

\begin{tabular}{|c|c|c|c|c|c|c|c|c|}
\hline Fraction & $\begin{array}{l}\text { Arsenic } \\
\text { (As) } \\
\end{array}$ & $\begin{array}{l}\text { Cadmium } \\
\text { (Cd) }\end{array}$ & $\begin{array}{l}\text { Chrome } \\
\text { (Cr) }\end{array}$ & Copper (Cu) & $\begin{array}{l}\text { Mercury } \\
\text { (Hg) }\end{array}$ & $\begin{array}{l}\text { Lead } \\
(\mathrm{Pb})\end{array}$ & $\begin{array}{l}\text { Nickel } \\
\text { (Ni) } \\
\end{array}$ & $\begin{array}{l}\text { Zinc } \\
\text { (Zn) }\end{array}$ \\
\hline $\begin{array}{l}\text { Construction } \\
\text { material }\end{array}$ & 10 & 0,2 & 40 & 40 & 0,1 & 20 & 35 & 120 \\
\hline Landfill cover & 10 & 1,5 & 80 & 80 & 1,8 & 200 & 70 & 250 \\
\hline $\begin{array}{l}\text { Waste } \\
\text { incineration }^{1}\end{array}$ & 12 & 12 & 100 & 700 & 3 & 500 & 40 & - \\
\hline Fines & 20 & 37,5 & 207 & 11000 & 2,7 & 3080 & 210 & 8500 \\
\hline Light waste & 6 & 36 & 99 & 15000 & 1 & 960 & 97 & 8300 \\
\hline Heavy waste & 6 & 19 & 500 & 7700 & 0,6 & 670 & 300 & 12000 \\
\hline SLF & 17 & 48 & 230 & 22000 & 2,6 & 2300 & 220 & 8400 \\
\hline
\end{tabular}

${ }^{1}$ Grate furnace

References: Personal communication, H. Söderberg, June 24, 2014: Swedish EPA, 2010.

\footnotetext{
${ }^{4}$ Particle size less than 5-7 $\mathrm{mm}$ is difficult to sort out in a recycling facility (personal communication, $\mathrm{H}$. Lorentsson, January 23, 2015)
} 
Table 4. The combustion values and TOC levels of the separated fractions as well as input criteria for cement production, waste incineration and disposal.

\begin{tabular}{|c|c|c|c|c|c|}
\hline Fraction & $\begin{array}{l}\text { Calorific Value } \\
(\mathrm{MJ} / \mathrm{kg})\end{array}$ & $\begin{array}{l}\text { Ash } \\
(\%)\end{array}$ & $\begin{array}{l}\text { Moisture } \\
(\%) \\
\end{array}$ & $\begin{array}{l}\text { Chlorine } \\
(\%)\end{array}$ & $\begin{array}{l}\text { TOC } \\
(\%)\end{array}$ \\
\hline Cement production & $>17$ & 2 & 8 & 0,8 & \\
\hline Waste incineration $^{1}$ & $8-16$ & 20 & $25-47$ & $1-1,5$ & \\
\hline Disposal $^{2}$ & & & & & $5 \%$ \\
\hline Fines & 10 & 57 & 27 & 1,9 & $27 \%$ \\
\hline Light waste & 27 & 22 & n.a. & 3,9 & $58 \%$ \\
\hline Heavy waste & 29 & 22 & 16 & 1,9 & $62 \%$ \\
\hline SLF & 17 & 44 & 22 & 2,3 & $39 \%$ \\
\hline
\end{tabular}

${ }^{1}$ Grate furnace and CFB boiler

${ }^{2}$ Nonhazardous landfill

References: Personal communication, H. Söderberg, October 15, 2014; Swedish EPA, 2004:1.

Incineration plants are probably not interested in receiving the fines. Certainly, the average heating value and moisture content in fines are acceptable for waste incineration, but too low for cement production, as seen in Table 4. But the ash content on the other hand, around $57 \%$, is too high for waste incineration $(20 \%)$ and especially cement production (2\%). In addition, concentrations of heavy metals are too high as demonstrated in Table 3, for example the copper concentrations are at least 15 times the gate requirements of combustion plants. The presence of chlorine is also too high for waste incineration and cement production. Fines could probably not be used as construction material, nor for construction works or landfill cover due to high levels of heavy metals such as chromium, nickel, mercury, and especially lead and copper. The lead and copper content was 150 times higher than the limits for using the masses in construction works, as seen in Table 3. Although the leaching concentrations of the fines were within the limits to be landfilled, see appendix, the content of organic waste $(25 \%)$ was higher than the permitted levels (5-6\%), as a consequence of the prohibition against deposition of organic material, Table 4.

\subsection{Flotation waste and SLF}

Heavy waste from the flotation accounted for about $20 \%$ of the excavated material and was the most homogeneous fraction with low levels of fine material (1\%) and the largest content of a specific material, rubber (81\%), in addition to smaller amounts of hard plastic, wood, and non-ferrous metals, as visualized in Table 2. Light waste from the flotation accounted for about $6 \%$ of the excavated material, demonstrating a similar material composition to heavy waste containing mainly rubber (51\%), but higher levels of fine material, hard plastic, non-ferrous metals, and lighter materials such as textiles. Waste from the air knife, i.e., SLF, represented approximately $11 \%$ of the excavated waste and contained mainly rubber and plastic, just like the flotation waste. But SLF was also the fraction with the largest proportion of lightweight material in the form of textiles (8\%), foam (8\%) and foil (4\%).

Although flotation waste and SLF demonstrate a high content of rubber, it is hardly interesting for pyrolysis producers, since none of the fractions contains rubber homogeneously. Even if it would be 
possible to homogenize the fractions, all fractions would still contain an unknown mixture of different types of tires from different decades, making it difficult to identify the original type of carbon black, as requested by pyrolysis producers (see appendix for detailed input criteria). Furthermore, the plastic content is too low to be recycled. However, it could be interesting, just as with fines, to reprocess the flotation waste and SLF to squeeze out the remaining nonferrous metals.

Incineration of these waste fractions was not likely. The calorific value of heavy waste, light waste and SLF are acceptable as fuel in cement industry but too high for waste incineration, as indicated in Table 4. On the other hand, the moisture content of heavy waste, light waste and SLF was too high for cement production but acceptable for waste incineration. The analysis of the moisture level of light waste failed ${ }^{5}$. Concentration of heavy metals, chlorine as well as the ash content of flotation waste and SLF also proved too high for waste incineration and cement production. The high levels of heavy metals also prevented the flotation waste and SLF to be used as construction material, as demonstrated in Table 3. In addition, the size of materials in these waste fractions is relatively large $(2-8 \mathrm{~cm})$, which possibly makes them less useful in some construction works, considering that the standard construction material in Sweden is gravel from crushed rocks. Re-deposition is not possible, due to the large amount of rubber and plastic, which gives a high organic level in the waste, Table 4 and Figure 3.

\subsection{Metals}

The sorted metal fraction accounted for $8 \%$ of the exhumed waste, of which $47 \%$ was iron, $18 \%$ aluminum and a mixed fraction with mainly copper (35\%). These metal fractions were sold to smelters in Asia in a quality class comparable to metals in ash from waste incinerators, which in general is a lower quality metal. The smelters were not informed that the metals previously were deposited. But on the other hand, the smelters have not complained about the quality. Since the metal fractions could be sold and thus recycled, no other outlets were examined.

\footnotetext{
${ }^{5}$ The sample was dried before analysis and the moisture level of $6 \%$ therefore became misleading.
} 


\begin{tabular}{|c|c|c|c|c|}
\hline & RECYCLE & INCINERATION & $\begin{array}{l}\text { CONSTRUCTION } \\
\text { MATERIAL }\end{array}$ & LANDFILL \\
\hline FIN & & & ) & $F_{n}$ \\
\hline LIG & & & & \\
\hline HEA & & (4) 00 & & \\
\hline SLF & & & & \\
\hline
\end{tabular}

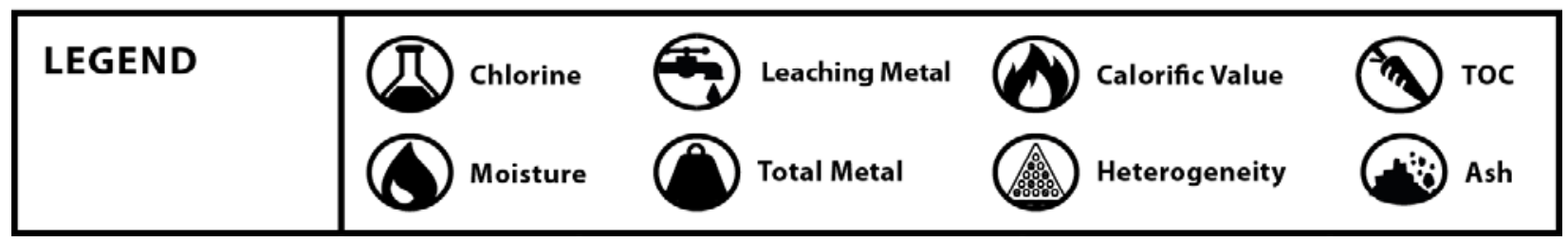

Figure 3. Overview of the separated fractions and the reasons for lacking marketability. The legend represents unacceptable levels of specified substances. A small symbol indicates a level close to the input criteria.

\section{DISCUSSION}

This case demonstrates the technical difficulties of refining previously disposed waste into marketable resources. Although advanced separation methods were applied, the metal fraction, which represented only $8 \%$ of the sorted masses, was the only fraction with a possible direct outlet. Consequently, $92 \%$ of the material had no resort. Not even deposition was possible because of the ban on landfilling organic waste (SCS, 2001:512).

As mentioned in the introduction, previous studies have not systematically examined marketability, as only a few fractions have been targeted. But these few examples can nevertheless be used for comparison and validity, because each case is specific with respect, for example, to the character of the disposed material, separation systems and site-specific conditions. For example, excavation of a shredder landfill in Denmark, similar to the one analyzed in this paper, was stopped since the material was too wet to be sorted into marketable fractions (Rosendal, 2015). Pilot studies targeting municipal landfills such as Sweden's largest, Filborna, in Helsingborg (Hogland et al., 1995; Karlsson and Åslund, 2014) and one located in Kuopio, Finland (Kaartinen et al., 2013), typically demonstrate lower levels of TOC, moisture, chlorine, ashes and heavy metals than the shredder landfill analyzed in this paper. But this is still slightly too high to be re-disposed, used as construction material or considered acceptable for incineration.

Similar difficulties in finding an outlet have also been experienced in non-European countries. For example, the levels of TOC, moisture, ash and heavy metals in masses from a Thai municipal landfill were probably non-acceptable for incineration plants as well as to be used as fertilizer according to Prechthai et al. (2008). 
Exhumed waste from landfills in the US had difficulties in meeting the gate requirements of incineration plants (Kornberg et al., 1993), due to low calorific value and high ash content. Krogmann and Qu (1997), in a review of US landfill mining projects, revealed that the fraction with highest marketable potential was the fine fraction to be used as landfill cover ${ }^{6}$. Even previously disposed metals have been reported difficult to market. In earlier pilot studies where metals have been sorted with the help of a magnet in a mobile separation plant, the quality of the metals was assumed to not be marketable (Stessel and Murphy, 1991; Savage et al., 1993; EPA, 1997; Hull et al., 2005; Jain et al., 2013). Not even when more advanced facilities optimized for metals were applied, equipped for example with electromagnets, eddy current magnets as well as sensors, do separated metals seem to reach marketable quality (Rosendal, 2015). Also after adopting flotation, as in this case, the quality of the metals proved low but nevertheless marketable.

Deposited waste seems consistently difficult to market. However, the reason might be that the extraction of deposited waste has, at least in this case, been conducted with technology and contrasted to market requirements adapted to "fresh" waste. Thus, in order to exploit the potential in landfills, we should evaluate how technology as well as policies, which largely determine market requirements, can better be adapted to deposited waste. Overall, four different approaches for enhancing the marketability of deposited waste can be identified. To obtain marketable materials from large-scale operations, dilution has been a common method (Hull et al., 2005; Wagner and Raymond, 2015). Since the sorting methods applied in landfill mining operations have typically been developed to process fresh waste rather than disposed waste, the sorting process has therefore in some cases been supplemented by either pretreatment processes (EPA, 1997; Rosendahl, 2015), or process modification and after-treatment processes to enhance the quality of the sorted waste (Schachermayer et al., 2000; Allegrini et al., 2014). Another approach, which never touches the waste, is to change the institutional conditions affecting the outlets of disposed waste (Van Passel et al., 2013; Johansson, 2013; Johansson et al., 2014).

\subsection{Dilution}

In cases where recovery has been successful on a large scale, such as the energy recovery of 200,000 tonnes of waste from Frey Farm Landfill in the US state of Pennsylvania (EPA, 1997), and recycling of 34,000 tonnes of ferrous and non-ferrous metals from ash landfill in the US state of Maine (Wagner and Raymond, 2015), dilution made these fractions marketable. For example, in Pennsylvania the previously deposited waste was mixed up with four times as much wood and other selected residual material to reach a quality equivalent to household waste (Forster, 1994, referenced in Hull et al., 2005). Nonetheless, this mixture proved to have "greater equipment wear, ash generation, and chloride emissions" than regular waste. In Maine, before sending the metals to smelters, the metals were processed and mixed with metals from an auto-shredder facility to upgrade the quality.

Dilution may, however, prove difficult if the operator does not receive large amounts of "pure" waste, which is the case for the owner of the shredder landfill analyzed in this case. But even if the landfill owner had access to clean waste, dilution would probably not have been a viable method. For example, at least 100 times as much copper-free waste needs to be added to the separated fractions to reach the limits of

\footnotetext{
${ }^{6}$ However, the need for covering old landfills, as a result of stricter legislation, will diminish over time.
} 
construction material, as seen in Table 3. For incineration, at least 10 times copper-free waste needs to be added. In order to reach the TOC limits of deposition, the fractions in this case need to be diluted with between 5 to 12 times TOC-free waste, as seen in Table 4. The metal fractions could however perhaps be diluted with "fresh" scrap as to increase the overall quality of the fraction. However, dilution means that the source of the problem is not addressed, as for example the total amount is never reduced in the fraction, only adulterated to fall within the levels. This makes the regulatory status of this method uncertain.

\subsection{Pre-Treatment}

Another way to increase the marketability of waste is to treat and improve the quality of the waste, either by modifying the existing process or adding treatment steps before or after the existing process. Some treatment methods are best suited before the existing process. For example, drying the sorted waste after the existing process may indeed lower the moisture level and thereby improve the possibilities for incineration. But if the waste instead is dried before the existing process, the efficiency of the sorting methods will also increase, as drier waste is easier to mechanically separate (cf. Maul and Pretz, 2016). This is especially true if dry separation methods such as air knife and screening are applied, separating by weight and size, respectively, since these methods depend on the material being easily detached. Hence pre-treatment, such as drying, can potentially acclimatize the deposited waste to the properties of the intended process.

The problem with moisture in the disposed waste is a recurring problem in landfill excavations (cf. Stessel and Murphy, 1991; EPA, 1997; Hull et al., 2005; Kaartinen et al., 2013; Rosendal, 2015; Wagner and Raymond, 2015), and created significant problems in this case, too. Even though the shredder waste in this case was stored for three months before processing to dry, only the surface layer of the waste piles seemed to have dried. Therefore, the processed waste had a humidity of $25 \%$, which meant that the fine material attached to bigger particles (cf. Kaartinen et al., 2013) and small and light materials could only occasionally be sorted through the screeners and air knife. The inefficient separation made many of the fractions have a similar material composition (see Tables 2, 3 and 4). For example, the SLF fraction, sorted through the air knife, contained more heavyweight waste (over $60 \%$ rubber and plastics) than light waste ( $20 \%$ textiles and foam) and a large portion of fine material. The presence of material in the SLF fraction that normally does not belong there such as PVC plastic and fines, increased the chlorine level and the ash content, respectively. In addition, the presence of fines probably also increased the levels of heavy metals, since the smallest particles are believed to contain the most toxic compounds (cf. Allegrini et al., 2014). This jointly reduced the combustion potential of the SLF fraction even further, given an already high moisture level.

Although wet separation, including washing was better adapted to handle humid waste, not least proved by the fact that metals could actually be marketable, the efficiency of the flotation plant was, however, also negatively affected by the high humidity. A large share of the light material, such as paper, wood and textiles, which otherwise ends up in the SLF fraction through the air knife, ended downstream in the flotation waste. So one way to increase the quality of the fractions sorted in the shredder plant is to initially reduce the moisture level of the previously disposed waste. But as this case demonstrates, storing is not 
enough to dry the waste, probably since the large amounts of soil and dirt in the waste, from the biodegradables, binds liquid. So to reduce the moisture level, in order to enhance the separation of the material, some form of mechanical dryer is probably required. In Denmark, by blowing hot air into the exhumed shredder waste and rotating it for three days, the moisture level decreased from $25 \%$ to $10 \%$ (Rosendal, 2015). This method proved, however, to be economically costly and area-intensive.

\subsection{Process modification and after-treatment}

While some treatment methods should be placed prior to the process, other methods fit better in the existing process or afterwards. The stationary recycling plant applied in this case was obviously not optimized for processing previously disposed waste, as only one out of five sorted fractions had an outlet. To improve the outcome, the existing process could be modified by adding sorting steps, for example, various forms of wet separation (cf. Jordão et al., 2016; Reddy et al., 2011; Schachermayer et al., 2000), which are less sensitive to moisture. Although washing the waste in this case prior to the flotation process proved not very helpful, additional, harder washing could potentially remove surface defilements that bind different materials together. Wet separation methods such as vertical or horizontal vibration may also increase the separation efficiency (Burtally et al., 2003; Mohabuth \& Miles, 2005). But modifying the existing process will most likely impair the plant's capacity to process the type of waste it was originally built for. So if the plant after the landfill mining operation shall go back to processing its intended waste streams, it is probably better to keep the existing process intact and instead place additional sorting steps afterwards. The advantage of placing various types of sorting steps after the existing process is that each sorted fraction can be refined according to the intended outlet and its requirements.

In order to determine appropriate outlets for the sorted fractions from the shredder facility and thereby guide the discussion on treatment methods, experience from previous landfill mining studies can be used. For example, the two large-scale examples mentioned above, which managed to recover some fractions through dilution, landfilled all the residues (Wagner and Raymond, 2015; Hull et al., 2005). But deposition is probably not a viable option for the shredder waste sorted in this case, considering the difficulties to reduce the organic content. For example, the material with high levels of organics such as plastic and rubber could be reduced by limiting the size settings in the screener even further, to achieve a fraction with fine-grained material, but hardly to the degree that the TOC content drops below 5-6\%. Furthermore, fossil plastics and rubber will naturally not biodegrade in the foreseeable future. Above all, from an economic perspective re-deposition should be avoided due to the generally high value of new landfill space (cf. Frändegård et al., 2015; Wagner and Raymond, 2015).

\subsubsection{Fines}

The outlet commonly proposed for fines, besides depositing, is the use of construction material (cf. Krogmann and Qu, 1997; Jain et al., 2013; Quaghebeur et al., 2013 Allegrini et al., 2014), which also seems technically most reasonable in this case. The advantage of using fines as construction material is that there are no specified maximum levels of organics (Swedish EPA, 2010). The requirements instead target heavy metal levels, as seen in Table 3. One way to reduce the level of heavy metals is to squeeze 
out remaining metals. However, reprocessing the fines in the shredder facility is probably not an efficient measure, since there was probably a reason why the metals were not separated from the waste in the first process, for example, particle size less than $5-7 \mathrm{~mm}$ is difficult to recycle (personal communication, $\mathrm{H}$. Lorentsson, January 23, 2015). There are other sorting techniques optimized for fine-grained materials suitable for recycling (cf. Schachermayer et al., 2000; Huang et al., 2010; Allegrini et al., 2014), which would be more appropriate in this case. Attempts to separate metals from fine-grained materials have demonstrated variable results depending on the waste type.

Optical sensor sorting of "fresh" waste has demonstrated that $98 \%$ of three different types of nonferrous metals could be recovered (Huang et al., 2010). However, waste with darker nuances did not reflect back to the sensor (ibid.). Since dirt, at least in this case, penetrates deep into the pores of the disposed material and proved difficult to wash off, optical sensors are probably less suitable for processing disposed waste (cf. Rosendal, 2015).

Mechanical wet separation adapted for fine material has demonstrated that, in the best cases, $97 \%$ of the total zinc can be sorted, which potentially could make the fines acceptable for construction material (Schachermayer et al., 2000). However, even if zinc could be sorted, high concentrations of other metals such as copper would remain. Furthermore, while some of the metals with high concentrations, such as copper and zinc, are likely to occur in the form of small pieces, other metals are probably present as chemically bonded and cannot be sorted mechanically. Hence, additional processes are required to upgrade the residues such as soil washing. Previous projects with soil washing (e.g. Swedish EPA, 2006) have demonstrated that the metal concentrations in fine fractions can be reduced to acceptable levels for building materials in construction works, while the heavy metals in the liquid phase are deposited or in the best case picked out for recycling (cf. Fedje et al., 2012).

\subsubsection{Flotation waste and SLF}

For coarser fractions, in this case SLF and flotation waste, incineration is often a proposed outlet (cf. Hull et al., 2005; Jain et al. 2013; Quaghebeur et al., 2013 Allegrini et al., 2014), which technically also seems most reasonable in this case. It is probably not possible to reach, trough mechanical sorting these fractions, recyclers' demands for homogeneity, lack of impurity and knowledge of sources (cf. Zhou et al., 2014). In order to increase the incineration potential of disposed waste, wet methods have been suggested (Bosman et al., 2013). But in this case, initial drying would probably be a better method, since it involves a smaller process adjustment, reduces the unacceptable moisture levels and could increase the efficiency of the screener and sort out more fine material such as ashes.

But a lower ash content means that the calorific value would increase in the SLF and the flotation waste. Therefore these fractions would be better suited as fuel for cement production, as waste incineration plants are adapted to household waste with its lower calorific value. But since plastic and rubber with high levels of PVC would remain in the fractions, the levels of chlorine would still be too high to be used as fuel. PVC can probably be sorted if the flotation plant in the fragmentation facility is set to sort plastic (instead of metal). Thereby, the flotation could sort plastic and rubber with high density, such as PVC, but also other plastic types such as low-density polyethylene. But even if the plastics can be sorted out in relatively 
homogeneous and pure fractions, Zhou (2014) argues that previously deposited plastic is not suitable for recycling due to high levels of impurities, and should therefore be energy recovered. Furthermore, the TOC content of PVC is probably too high to be re-deposited, the origin too uncertain for pyrolysis, and too biologically stable for composting. Hence, this type of disposed plastic lacks outlets. So only certain types of plastics - thermoplastics such as PE and PP - could be recovered.

\subsection{Altering the institutional conditions}

A fourth way to increase the marketability of disposed waste is to change the legal framework hindering deposited waste from being recovered. The prevailing institutional conditions for waste materials are adapted to "fresh" waste, just like the applied technologies, and therefore, like the treatment methods, could be modified to increase the marketability. Changes in the regulatory framework have been discussed earlier on a general level, for example by Johansson (2013), who suggested more equal institutional conditions between primary mining targeting virgin resources and secondary mining targeting waste. To increase the economic potential of landfill mining, Van Passel et al. (2013) suggested subsidies in the form of green power certificates. However, less research has been done on how to increase the market acceptance for disposed waste by changing the regulatory frameworks. Below, the regulatory framework of the outlets, which are controlled by regulatory requirements in the form of deposition and construction materials will be discussed. The market acceptance for incineration, but especially material recycling, is to a greater extent determined by the individual operator and thus more difficult to influence directly by regulatory changes and relies primary on business-to-business relations.

Many of the regulations that pose barriers in a landfill mining operation, however, have important positive effects and have contributed to mitigating different problems. The ban on landfilling organic waste, for example, reduces emissions of methane while the regulatory landfill framework has brought management practices up in the waste hierarchy. Removing laws is thus not a desirable option. The solution of the disposal problem in the case analyzed in this paper was an exception from the landfill bans. According to the permit granted by the municipality, dispensation was given to re-deposit all residues from the pilot study. This is also in line with the criteria for exemptions according to the Swedish EPA (2004:10), which can be given in cases when the waste's "physical or chemical properties after-treatment are not recyclable or couldn't be discarded in ways other than landfilling" [translated from Swedish]. However, exceptions are only possible when explicitly stated in the legislation. Furthermore, exemptions are not a long-term solution, since there is always a risk that the licensing authority makes a negative assessment.

\subsubsection{Regulatory flexibility}

A better solution than exemption is probably if the authorities could adopt a regulatory flexibility. Experiences for such a regulatory approach can be taken from continental European countries where primary resources tend to be scarce in contrast to Sweden. In these countries, the pressure to use waste as a resource has encouraged greater flexibility, demonstrated in their assessment of waste and the tradeoffs between the importance of resource circularity on the one hand and the risk of pollution on the other.

In Sweden, there are currently only suggested values for the use of waste for landfill cover or for construction works (Swedish EPA, 2010). But in Denmark, for example, specific values have been 
formulated for different types of construction works with different risks of leaching and exposure. This means that depending on the impurity level of the waste, the waste could be assigned to different construction applications. For example, the requirements on using waste as construction materials for building the foundation of residential areas is stricter than for asphalt roads (Miljøministeriet, 2012). Furthermore, in order to create a market for the waste, the state has become an important costumer, using waste in large infrastructure projects (Sahlin, 2013; Van Beers et al., 2009). In public procurement, additional green criteria could be added in the tender, beyond the traditional economic criteria.

A comparison between the suggested values in Sweden and in Flanders (Belgium) for the use of waste as construction material, Table 5, demonstrates a differentiated approach towards the presence of heavy metals. For using waste as construction material without special permission, the total levels of lead need to be 60 times lower in Sweden than in Flanders. This does not necessarily entail a greater risk, since although the Flemish rules are more liberal with total levels, the allowed concentrations for leaching of heavy metals such as chromium, copper and zinc are lower in Flanders than Sweden, as seen in Table $5^{7}$.

Table 5. Swedish and Flemish values for using waste as construction material.

\begin{tabular}{|l|ll|ll|}
\hline Metals & \multicolumn{2}{|l|}{ Total concentration (mg/kg dry matter) } & \multicolumn{2}{l|}{ Leaching concentration (mg/kg dry matter) } \\
\hline & Sweden & Flanders & Sweden & Flanders \\
\hline Arsenic (As) & 10 & 250 & 0.09 & 0.8 \\
Cadmium (Cd) & 0,2 & 10 & 0.02 & 0.03 \\
Chrome (Cr) & 40 & 1250 & 1 & 0.5 \\
Copper(Cu) & 40 & 375 & 0.8 & 0.5 \\
Mercury (Hg) & 0.1 & 5 & 0.01 & 0.02 \\
Lead (Pb) & 20 & 1250 & 0.2 & 1.3 \\
Nickel $(\mathrm{Ni})$ & 35 & 250 & 0.4 & 0.75 \\
Zinc $(\mathrm{Zn})$ & 120 & 1250 & 4 & 2.8 \\
\hline
\end{tabular}

References: Swedish EPA, 2010; Flemish government, 2012.

Some of the fractions sorted from the fragmentation facility contain total concentrations of cadmium, copper and lead also exceeding the Flemish guiding limits. Hence, changing institutional conditions cannot replace the internal valorization of the material, but needs to go hand in hand. But marketability is a complex issue, particularly if the disposed waste shall be recovered. Unlike deposition, the use of deposited waste as construction material, sending it to incineration or material recycling involves a customer who will use the garbage. So although it could be possible to obtain sufficiently clean waste fractions by mechanical sorting or lowering the input criteria, acceptance cannot be assured. As long as waste receivers have a sufficient supply of their conventional commodities, to which their technologies, knowledge, regulatory understanding and organization have been adapted accordingly, there is no incentive to accept uncertain raw material such as deposited waste. For example, in Sweden the availability of construction materials in the form of gravel is both cheap, extensive and clean, which means there is no motive for clients to use waste as construction material in, for example, infrastructure projects.

\footnotetext{
${ }^{7}$ The comparison of the Swedish and Flemish guiding limits also shows that market requirements may differ greatly between countries, therefore the developed framework should only be used in other countries with caution.
} 
For the same reason, domestic incinerators have no motive to accept deposited garbage, as long as several European countries are willing to pay high gate fees to get rid of their high-quality waste after implementation of landfill bans. Hence, institutional and technical changes must be followed by a changed perception towards waste, especially concerning waste buried in landfills. To drive this development, the state could establish a market, for example, by becoming a customer for previously deposited material (cf. European Commission, 2015).

\section{CONCLUSIONS}

The demand for materials is increasing, driven by a growing population and economy, which leads to a focus on unconventional resource stocks, for example in landfills. But in parallel with an increasingly resource-hungry market, the market and regulatory requirements for secondary resources have become stricter. In addition, the quality of buried and hidden material has over time deteriorated and could contain substances phased out long ago. Altogether this prevents resources in landfills from getting another chance. Even in the best cases, when some material from a landfill could be recovered, such as metals, the outlet of the other materials would still be unpredictable, resulting in an unpleasant waste disposal problem, which easily prevents a landfill mining project altogether. This calls for marketability and usability of deposited waste to become a central issue for landfill mining research. Marketability should no longer be mentioned only in passing or assumed on hypothetical grounds: what is the marketability for other types of disposed waste, for example in a municipal landfill, situated in other institutional contexts? Landfill mining research needs to mature and go beyond its focus on estimating potential to instead try to understand how landfill mining operations can be realized through a combination of institutional, technical and organizational approaches that potentially enhance the marketability of disposed waste. But marketability of deposited resources is certainly more than just a research question, as concerned actors need to demonstrate a greater openness to the unconventional.

For example, actors directly involved in landfill mining operations cannot settle for processing the waste with the accessible, on-site existing sorting methods, since these are often adapted for other purposes and waste types. Treatment methods with a potential to acclimatize the deposited waste to existing processes should be evaluated. But additional technologies could also be necessary after the process, as this case demonstrated, to refine the quality of sorted waste fractions to potentially become acceptable for the market. The receivers of the sorted waste, downstream in the process chain, also need to demonstrate a greater openness and acceptance for unconventional waste from landfills. For example, the over-capacity of Swedish waste incinerators will not be filled forever by cheap household waste from countries with an undersized waste management system. Therefore, they have a reason to explore new stocks of combustibles, including those buried sometimes located next to their facility.

But for concerned actors to become interested in approaching unconventional resources such as deposited waste, political clarity is required. There are currently a number of Swedish policy objectives such as increased recycling, remediation, reduced climate impact and resource conservation, which can be met by the single action of a landfill mining operation. But at the same time, the regulatory framework close to the market prevents such projects, for example by prohibiting and taxing re-deposition and restricting the possibilities for using the waste as construction material. One way to harmonize the policy 
objectives with the regulatory framework is to allow radical solutions such as landfill mining to adopt a greater flexibility in the governmental assessment of projects. Re-deposition of the fines from the shredder landfill could, for example, be approved even though containing a small percentage or higher of organic substances. Or, the authorities could allow higher emissions from the incinerator than permitted. But this would only be if the environmental benefits of the projects outweigh the disadvantages, for example through combining the recycling practices with handling hazardous material, remediation and after care. In such cases, the authorities must be able to weigh pollution risks in the form, for example, of increased leaching, transport and odor as a result of a landfill mining operation with its potential in terms for example of avoided primary production and remediation.

\section{ACKNOWLEDGEMENTS}

Funding and employment was provided by the Swedish Innovation Agency, VINNOVA.

\section{REFERENCES}

Alburquerque, J. A., de la Fuente, C., Ferrer-Costa, A., Carrasco, L., Cegarra, J., Abad, M., \& Bernal, M. P. (2012). Assessment of the fertiliser potential of digestates from farm and agroindustrial residues. Biomass and Bioenergy 40: 181-189.

Allegrini, E., Maresca, A., Olsson, M.E., Holtze, M.S., Boldrin, A., Astrup, T.F., (2014). Quantification of the resource recovery potential of municipal solid waste incineration bottom ashes. Waste Manag. 34: 1627-1636.

Alm, J., Christéen, J. Collin, G., (2006). Landfill mining at Stena Gotthard's landfill in Halmstad. An environmental and economic evaluation. Master's Thesis. Linköping University

Ayres, R. (1999) The second law, the fourth law, recycling, and limits to growth. Ecological Economics 29: 473-484.

Bosmans, A., Vanderreydt, I., Geysen, D., \& Helsen, L. (2013). The crucial role of Waste-to-Energy technologies in enhanced landfill mining: a technology review. Journal of Cleaner Production, 55, 1023.

Burtally, N., King, P. J., Swift, M. R., \& Leaper, M. (2003). Dynamical behaviour of fine granular glass/bronze mixtures under vertical vibration. Granular Matter, 5(2), 57-66.

Cossu, R., Motzo, G.M., \& Laudadio, M. (1995). Preliminary study for a landfill mining project in Sardinia. Proceedings Sardinia 95, Fifth International Landfill Symposium, Cagliari, Italy: 841-850

Cossu, R., W. Hogland \& E. Salerni (1996). Landfill mining in Europe and the USA. ISWA Year Book 1996: 107-114.

Dickinson, W. (1995). Landfill mining comes of age. Solid Waste Technologies 9: 42-47.

EPA (1997). Landfill reclamation. EPA 530-F-97-001, United States Environmental Protection Agency.

European Commission (2008) The Raw Materials Initiative-Meeting Our Critical Needs for Growth and Jobs in Europe. Communication, COM(2008)699. Brussels.

European Commission (2015) Closing the loop - An EU action plan for the Circular Economy. Communication COM/2015/0614. Brussels.

European Parliament (2008) Directive 2008/98/EC on waste. Official Journal of the European Union L 312: 3-30.

European Parliament (2009). Appendix XVII REACH. no. 552/2009. The European Union Official Journal 164: 7-31. 
Fedje, K. K., Ekberg, C., Skarnemark, G., Pires, E., \& Steenari, B. M. (2012). Initial studies of the recovery of $\mathrm{Cu}$ from MSWI fly ash leachates using solvent extraction. Waste Management \& Research 30(10): 1072-1080.

Fisher, H. \& Findlay, D. (1995). Exploring the economics of mining landfills. World Wastes 38: 50-54.

Flemish government (2012). VLAREMA: the sustainable management of material cycles and waste. Annex 2.3.2. Conditions for use as building material. [online] https://navigator.emis.vito.be/mijnnavigator?wold=44707 [Accessed 2015-05-19]

Frändegård, P., Krook, J., Svensson, N. \& Eklund, M. (2013). A novel approach for environmental evaluation of landfill mining. Journal of Cleaner Production 55: 24-34.

Frändegård, P., Krook, J., \& Svensson, N. (2015). Integrating remediation and resource recovery: On the economic conditions of landfill mining. Waste Management 42: 137-147.

Frändegård, P., Krook, J., Svensson, N. \& Johansson, N. (forthcoming). Exploring the economic and environmental performance of a landfill mining project - A feasibility study from the viewpoint of an industrial landfill owner.

Hino, J., Miyabayashi, Y. \& Nagato, T. (1998). Recovery of nonferrous metals from shredder residue by incinerating and smelting. Metallurgical Review of MMIJ (Mining and Metallurgical Institute of Japan) 15: $63-74$.

Hogland, W., Jagodzinksi, K., \& Meijer, J.E. (1995). Landfill Mining Tests in Sweden. Proceedings of the fifth international Landfill Symposium, Cagliari, Sardinia, Italy, 2-6 October: 783-794.

Hogland, W., Marques, M. \& Nimmermark, S. (2004). Landfill mining and waste characterization: a strategy for remediation of contaminated areas. J. of Material Cycles and Waste Management 6: 119-124.

Huang, J., Pretz, T., \& Bian, Z. (2010). Intelligent solid waste processing using optical sensor based sorting technology. In Image and Signal Processing (CISP) 4: 1657-1661.

Hull, R.M., Krogmann, U. \& Strom, P.F. (2005). Composition and characteristics of excavated materials from a New Jersey landfill. J. of Environmental Engineering 131: 478-490.

Jain, P., Townsend, T. G., \& Johnson, P. (2013). Case study of landfill reclamation at a Florida landfill site. Waste Management 33(1): 109-116.

Johansson, N., Krook, J., \& Eklund, M. (2012). Transforming dumps into gold mines. Experiences from Swedish case studies. Environmental Innovation and Societal Transitions 5: 33-48.

Johansson, N., Krook, J., Eklund, M., \& Berglund, B. (2013). An Integrated Review of Concepts for Mining the Technosphere: Towards a New Taxonomy. Journal of Cleaner Production 55: 35-44.

Johansson, N. (2013). Why don't we mine the landfills? Licentiate thesis, Linköping University. Linköping, Sweden; LIU-tryck.

Johansson, N., Krook, J., \& Eklund, M. (2014). Institutional conditions for Swedish metal production: A comparison of subsidies to metal mining and metal recycling. Resources Policy 41: 72-82.

Jones, P. T., Geysen, D., Tielemans, Y., Van Passel, S., Pontikes, Y., Blanpain, B. \& Hoekstra, N. (2013). Enhanced Landfill Mining in view of multiple resource recovery: a critical review. Journal of Cleaner Production 55: 45-55.

Jordão, H., Sousa, A. J., \& Carvalho, M. T. (2016). Optimization of wet shaking table process using response surface methodology applied to the separation of copper and aluminum from the fine fraction of shredder ELVs. Waste Management 48: 366-373.

Kaartinen, T., Sormunen, K., \& Rintala, J. (2013). Case study on sampling, processing and characterization of landfilled municipal solid waste in the view of landfill mining. Journal of Cleaner Production 55: 5666.

Kapur, A. (2006). The future of the red metal: discards, energy, water, residues, and depletion. Progress in Industrial Ecology 3(3): 209-236. 
Karlsson, P., Åslund, P. (2014). Economic and environmental conditions for landfill mining: A pilot study of three different landfill types at Filborna plant in Helsingborg. Master's Thesis, Linköping University. [In Swedish]

Kornberg J.F., von Stein E.L. \& Savage E.L. (1993). Landfill Mining in the United States: An Analysis .of Current Projects. Proceedings Sardinia 93, Fourth International Landfill Symposium, Cagliari, Italy, 1115 October 1993: 1555-1561.

Krogmann, U., Qu, M. (1997). Landfill mining in the United States. Proceedings Sardinia '97, Sixth International Landfill Symposium, Cagliari: 543-552.

Krook, J., Svensson, N. \& Eklund, M. (2012). Landfill mining: A critical review of two decades of research. Waste Management 32(3): 513-520.

Krook, J., Johansson, N., Frändegård, P. (2015) Landfill Mining: On the Potential and Multifaceted Challenges for Implementation. In M. Taherzadeh and T. Richards (eds.), Resource Recovery to Approach Zero Municipal Waste: 313-327: CRC Press, London.

Maul, A., Pretz, T. (2016). Landfill Mining from the processing perspective - a view on mass balance and output streams. In Pereira, M. et al. (eds.) Proceedings of the International Symposium on Enhanced Landfill Mining, 2016: 403-413.

Mohabuth, N., \& Miles, N. (2005). The recovery of recyclable materials from Waste Electrical and Electronic Equipment (WEEE) by using vertical vibration separation. Resources, conservation and recycling, 45(1), 60-69.

Prechthai, T., Padmasri, M., \& Visvanathan, C. (2008). Quality assessment of mined MSW from an open dumpsite for recycling potential. Resources, Conservation and Recycling 53(1): 70-78.

Quaghebeur, M., Laenen, B., Geysen, D., Nielsen, P., Pontikes, Y., Van Gerven, T., \& Spooren, J. (2013). Characterization of landfilled materials: screening of the enhanced landfill mining potential. Journal of Cleaner Production 55: 72-83.

Reddy, M. S., Okuda, T., Nakai, S., Nishijima, W., \& Okada, M. (2011). Recovery of polypropylene and polyethylene from packaging plastic wastes without contamination of chlorinated plastic films by the combination process of wet gravity separation and ozonation. Waste Management 31(8): 1848-1851.

Reeves, T.S. \& Murray, G.C. (1997). Landfill mining - a tool for rural landfill management and closure. Proceedings of the Air and Waste Management. Association's 90th Annual Meeting and Exhibition. Toronto, Canada.

Rosendal, R. (2015). Personal communication with René Rosendal at the Danish Waste Association. 201505-18.

Sahlin, J., 2013. Internationell utblick om användning av askor. Profu \& Svenska Energiaskor AB.

Savage, G.M., Golueke, C.G., von Stein, E.L. (1993). Landfill mining: past and present. Biocycle 34: 58-61.

Schachermayer, E., Lahner, T., \& Brunner, P. H. (2000). Assessment of two different separation techniques for building wastes. Waste Management and Research 18(1): 16-24.

SCS (2001:512). Regulation on deposition of waste. Swedish Code of Statues. [In Swedish]

Stessel, R.I., Murphy, R.J. (1991). Processing of material mined from landfills. Proceedings of the National Waste Processing Conference, Publ. by ASME, Detroit, MI, USA: 101-111.

Swedish EPA (2004:10). Environmental Protection Agency regulations on landfill, criteria and procedures for the acceptance of waste at landfills. ISSN 1403-8234. [In Swedish]

Swedish EPA (2006). Solutions - Experiences and available methods. Report 5637. CM-Gruppen, Sweden. [In Swedish]

Swedish EPA (2010). Recycling of waste in constructions. Report 2010:1. CM-Gruppen, Sweden. [In Swedish] 
Swedish EPA (2012). The Swedish waste plan 2012-2017. [online] http://www.naturvardsverket.se/Miljoarbete-i-samhallet/Miljoarbete-i-Sverige/Uppdelat-efteromrade/Avfall/Avfallsplanen/ [In Swedish]

Swedish Government (2013). The Swedish Mineral Strategy. Elanders, Mölnlycke. [In Swedish]

Tanha, A., Zarate, D. (2012). Landfill Mining: Prospecting metal in Gärstad landfill. Master's Thesis, Linköping University.

Van Beers, D., Bossilkov, A., Lund, C., 2009. Development of large-scale reuses of inorganic by-products in Australia: The case study of Kwinana, Western Australia. Resources. Conservation and Recycling 53: 365-378.

Van Gerven, T., Van Keer, E., Arickx, S., Jaspers, M., Wauters, G., \& Vandecasteele, C. (2005). Carbonation of MSWI-bottom ash to decrease heavy metal leaching, in view of recycling. Waste Management 25(3): 291-300.

Van Passel, S., Dubois, M., Eyckmans, J., De Gheldere, S., Ang, F., Jones, P. T., \& Van Acker, K. (2013). The economics of enhanced landfill mining: private and societal performance drivers. Journal of Cleaner Production 55: 92-102.

Vermeulen, I., Block, C., Van Caneghem, J., Dewulf, W., Sikdar, S.K., Vandecasteele, C., (2012). Sustainability assessment of industrial waste treatment processes: the case of automotive shredder residue. Resour. Conserv. Recycl. 69: 17-28.

Wagner, T. P. and Raymond, T. (2015). Landfill Mining: Case Study of a Successful Metals Recovery Project, Waste Management 45: 448-457.

Winterstetter, A., Laner, D., Rechberger, H., Fellner, J. (2015). Framework for the evaluation of anthropogenic resources: A landfill mining case study-Resource or reserve? Resources, Conservation and Recycling 96: 19-30.

Zanetti, M. \& Godio, A. (2006). Recovery of foundry sands and iron fractions from an industrial waste landfill. Resources, Conservation and Recycling 48: 396-411.

Zhao, Y., Song, L. Huang, R., Song, L. \& Li, X. (2007). Recycling of aged refuse from a closed landfill. Waste Management Research 25: 130-138.

Zhou, C., Fang, W., Xu, W., Cao, A., \& Wang, R. (2014). Characteristics and the recovery potential of plastic wastes obtained from landfill mining. Journal of Cleaner Production 80: 80-86.

\section{APPENDIX: A MARKET FRAMEWORK FOR SECONDARY RESOURCES}

As specified in the method, the gate requirements for disposal, construction materials and energy recovery are presented quantitatively in Table 6, since there are general specifications, while the gate requirements for recycling are presented qualitatively in the following text as gate requirements are determined from case to case. 
Table 6. Overview of the input criteria in terms of total concentrations, leaching concentrations and heating values for disposal, construction material and energy recovery.

\begin{tabular}{|c|c|c|c|c|c|c|c|c|}
\hline & & \multicolumn{2}{|l|}{ Disposal } & \multicolumn{2}{|c|}{ Construction material } & \multicolumn{2}{|c|}{ Energy recovery } & \multirow[b]{2}{*}{ Cement } \\
\hline $\begin{array}{l}\text { Total } \\
\text { concentrations }\end{array}$ & & $\begin{array}{l}\text { Non- } \\
\text { hazardous }\end{array}$ & Hazardous & $\begin{array}{l}\text { Construction } \\
\text { works }\end{array}$ & $\begin{array}{l}\text { Landfill } \\
\text { cover }\end{array}$ & Waste & $\mathrm{CDF}$ & \\
\hline Moisture & wt\% & & & & & 25 & $18-47$ & 8 \\
\hline Ash & wt $\%$ & & & & & 20 & 20 & $1-2$ \\
\hline Chlorine, Cl & $\mathrm{wt} \%$ & & & & & 1 & 1.5 & 0.8 \\
\hline Sulfur, S & wt $\%$ & & & & & 0.6 & 1 & 0.7 \\
\hline Fluorine, F & wt $\%$ & & & & & & 0.03 & \\
\hline Nitrogen, $\mathbf{N}$ & wt $\%$ & & & & & & 2,2 & \\
\hline TOC & $\mathrm{wt} \%$ & 5 & 6 & & & & & \\
\hline Aluminum, $\mathrm{Al}$ & wt $\%$ & & & & & & 1 & \\
\hline Iron, Fe & wt\% & & & & & & 5 & \\
\hline Manganese, Mn & wt $\%$ & & & & & 0.04 & 0.05 & $\mathrm{C}$ \\
\hline Sodium, Na & wt $\%$ & & & & & & $\mathrm{a}$ & \\
\hline Potassium, K & wt $\%$ & & & & & & $\mathrm{a}$ & \\
\hline Copper, Cu & wt\% & & & 0.004 & 0.01 & 0.07 & 0.15 & $\mathrm{C}$ \\
\hline Zinc, Zn & wt $\%$ & & & 0.012 & 0.03 & & 0.2 & \\
\hline Bromine, Br & $\mathrm{mg} / \mathrm{kg}$ & & & & & & 10 & \\
\hline Vanadium V & $\mathrm{mg} / \mathrm{kg}$ & & & & & 10 & 300 & $\mathrm{C}$ \\
\hline Chromium, Cr & $\mathrm{mg} / \mathrm{kg}$ & & & 40.0 & 80.0 & 100 & 55 & C \\
\hline Cobalt, Co & $\mathrm{mg} / \mathrm{kg}$ & & & & & 4 & 200 & $\mathrm{C}$ \\
\hline Nickel Ni & $\mathrm{mg} / \mathrm{kg}$ & & & 35.0 & 70.0 & 40 & 500 & $\mathrm{C}$ \\
\hline Lead, Pb & $\mathrm{mg} / \mathrm{kg}$ & & & 20.0 & 200.0 & 500 & 10 & $\mathrm{C}$ \\
\hline Cadmium, Cd & $\mathrm{mg} / \mathrm{kg}$ & & & 0.2 & 1.5 & 12 & 300 & $\mathrm{D}$ \\
\hline Arsenic, As & $\mathrm{mg} / \mathrm{kg}$ & & & 10.0 & 10.0 & 12 & 37 & $\mathrm{C}$ \\
\hline Thallium, Tl & $\mathrm{mg} / \mathrm{kg}$ & & & & & 3 & 1.1 & d \\
\hline Antimony, Sb & $\mathrm{mg} / \mathrm{kg}$ & & & & & 0.7 & 45 & $\mathrm{C}$ \\
\hline Mercury, Hg & $\mathrm{mg} / \mathrm{kg}$ & & & 0.1 & 1.8 & 3 & 1.7 & 2 \\
\hline Heating value & $\mathrm{MJ} / \mathrm{kg}$ & & & & & $8-12$ & $8.5-16$ & $>17$ \\
\hline Material & & & & & & & b & \\
\hline $\begin{array}{l}\text { Leaching } \\
\text { concentrations }\end{array}$ & & & & & & & & \\
\hline Arsenic, As & $\mathrm{mg} / \mathrm{kg}$ & 2 & 25 & 0.09 & 0.4 & & & \\
\hline Barium, Ba & $\mathrm{mg} / \mathrm{kg}$ & 100 & 300 & & & & & \\
\hline Cadmium, Cd & $\mathrm{mg} / \mathrm{kg}$ & 1 & 5 & 0.02 & 0.007 & & & \\
\hline Chromium, Cr & $\mathrm{mg} / \mathrm{kg}$ & 10 & 70 & 1 & 0.3 & & & \\
\hline Copper, Cu & $\mathrm{mg} / \mathrm{kg}$ & 50 & 100 & 0.8 & 0.6 & & & \\
\hline Molybdenum, Mo & $\mathrm{mg} / \mathrm{kg}$ & 10 & 30 & & & & & \\
\hline Nickel, Ni & $\mathrm{mg} / \mathrm{kg}$ & 10 & 40 & 0.4 & 0.6 & & & \\
\hline
\end{tabular}




\begin{tabular}{|ll|ll|ll|}
\cline { 3 - 6 } Lead, Pb, & $\mathrm{mg} / \mathrm{kg}$ & 10 & 50 & 0.2 & 0.3 \\
Antimony, Sb & $\mathrm{mg} / \mathrm{kg}$ & 0,7 & 5 & & \\
Selenium, Se & $\mathrm{mg} / \mathrm{kg}$ & 0,5 & 7 & & 3 \\
Zinc, Zn & $\mathrm{mg} / \mathrm{kg}$ & 50 & 200 & 4 & 11000 \\
Chlorine, Cl & $\mathrm{mg} / \mathrm{kg}$ & 15000 & 25000 & 130 & \\
Fluorine, F & $\mathrm{mg} / \mathrm{kg}$ & 150 & 500 & & 0.01 \\
Mercury, Hg & $\mathrm{mg} / \mathrm{kg}$ & 0,2 & 2 & 0.01 & 8500 \\
\hline Sulfate, SO42- & $\mathrm{mg} / \mathrm{kg}$ & 20000 & 50000 & 200 & \\
\hline
\end{tabular}

$\mathrm{a}<2 \mathrm{wt} \%$

$\mathrm{b}<5 \mathrm{wt} \%$ Non-ferrous metals, $<2 \mathrm{wt} \%$ glass and $<3 \mathrm{wt} \%$ inert

c $<2500 \mathrm{mg} / \mathrm{kg}$

$\mathrm{d}<15 \mathrm{mg} / \mathrm{kg}$

References: Personal communication, H. Söderberg, June 24, 2014; Swedish EPA, 2010; Swedish EPA; 2004:10.

For plastic recyclers, the plastics content must be as high as possible, at least over $90 \%$, according to Sundhall (personal communication, January 23, 2015). Plastic recyclers commonly accept both mixed plastic fractions (i.e., low- and high-density polyethylene, PET and polypropylene) and sorted plastic fractions. Plastic recyclers normally do not accept waste containing PVC plastic, hazardous waste, glass, metals and stones, as the sorting machines may be damaged. However, they have the possibility to handle plastic waste containing clay, wood, textiles and rubber. If the plastic recycler suspects a potential risk in the waste, lab analysis will be requested, according to Cannerborg (personal communication, January 23, 2015). The results from the lab analysis are then compared with the candidate list of REACH (European Parliament, 2009), containing limits for hazardous materials in finished products. The levels of many heavy metals (e.g. $\mathrm{Pb}, \mathrm{Cd}, \mathrm{Hg}$ and $\mathrm{Cr}$ ) should be below $100 \mathrm{mg} / \mathrm{kg}$, according to Cannerborg (personal communication, January 23, 2015). However, the limits are different depending on the type of hazardous material (European Parliament, 2009). The limits are lower, for example, for cadmium, arsenic and mercury, but higher for iron (Cannerborg, personal communication, January 23, 2015; European Parliament, 2009).

Rubber can be recycled through pyrolysis. Pyrolysis is a form of thermal degradation, which heats up the material in a closed, oxygen-free environment, without burning it, disintegrating the rubber into its original components, for example coal, oil and carbon black. The pyrolysis producer is interested only in homogeneous rubber fractions where the original type of carbon black can be identified (Hagbyhn, personal communication, January 28, 2015).

Metal recyclers commonly have lower requirements than plastic and rubber recyclers. The waste fractions need of course to contain metals, but the accepted concentration depends largely on the type of metal, and the mixture of different metals. For example, higher iron concentration is required than copper concentration, due to different economic value. The recycling facilities for metals are not sensitive for nonmetallic content in waste fractions, and could for example hold permission to handle hazardous waste (Lorentsson, personal communication, January 23, 2015). However, the waste is not allowed to contain radioactive, infectious, pathological or corrosive substances. The presence of non-metallic substances such as hazardous waste may, however, add cost, as it must be deposited in special landfills, which means that the metal concentration must in such cases be considerably higher to be acceptable. 